\title{
5 Tracing the Finnish \\ Comprehensive Security Model
}

\author{
Vesa Valtonen and Minna Branders
}

\section{Introduction}

The provision of security and defence in modern societies struggles with growing threat complexity and a widening array of actors. As the UK Ministry of Defence put it in 2018, the

rate of change and level of uncertainty [in modern security governance] may outpace good governance and unity. The complex interaction of these trends is potentially a game changer and demands a new approach that places strategic adaptability at its core.

(MoD UK 2018, 11).

This chapter traces how Finland has reacted to such pressures both conceptually and in bureaucratic practice, namely, it deals with the emergence of the "comprehensive security" notion, which in Finland can be called a "Comprehensive Security Model" (CSM). The Finnish CSM suggests a certain governance model for how security should be addressed across societal and governmental levels, especially in an anticipatory fashion. It emphasises information sharing, preparedness planning, and effective implementation among multiple actors in different sectors. The CSM is in many respects a governance model, focused on coordination, a phenomenon-led approach, and firmly situated in the rule of law.

The chapter begins by reflecting on the Finnish comprehensive approach in relation to other concepts such as societal security and resilience. It then offers an overview of the Finnish approach, which is crystallised in practice by CSM, and outlines its key components. The chapter then traces the Finnish concept of comprehensive security as a public policy, analysing its development into a rather unique model of practice. The chapter poses a question: how and under what circumstances was the model developed? More specifically, how were the policy features involving comprehensive security interpreted, conceptualised, and put to work in Finland, and with what implications? The approach we use is document analysis at the strategic level, including white papers and steering documents, because comprehensive security is a strategy or state level concept. 
We argue that a number of key developments shaped today's Finnish approach to comprehensive security, including the historical context of wars fought by Finland and the resulting sense of trust and shared purpose that led to the notion of Total Defence. The post-Cold War security context and a widening threat perspective further enabled the emergence of a new approach to security thinking and practice, built on pragmatism and strongly backed by politicians. In this context, the CSM emerged as both a concept and a model of practice that included coordination within a common framework, regular interaction, and trust-building amongst officials. We conclude the chapter with an overview of enduring challenges to the CSM model, many brought by an increasingly complex threat environment, and reflect upon Nordic similarities and differences.

\section{The comprehensive security concept in comparative perspective}

The Finnish model of comprehensive security, especially in the context of this book, must be seen in relation to broader Nordic notions of "societal security". In a Nordic perspective, the concept of societal security has an ambiguous origin and can be linked both to the initial conceptualisation of the Copenhagen school of securitisation and to a later functional variant that broadened security practices across the region by bringing crisis management, preparedness, hybrid threats, and military discourses into the concept (Rhinard, this volume). Broadly speaking, societal security can be understood as a new approach to security that involves a wide set of considerations necessary to permit society to retain and underpin its identity and core values.

According to some studies, societal security is likely to become a dominant security policy referent object, in which all other phenomena, including national security, are subsumed (see Aaltola et al. 2018, 8). Nordic security research equates societal security and holistic security thinking with not only the identification of uncertainties and the resilience perspective but also the link between development to the security environment, the development of capabilities, and the knowledge base to promote security, and emphasises contexts such as the human, socio-technological, societal, political, organisational, and international (Nordforsk 2013). Societal security has clear consequences for society and its functioning, social institutions, civil society, and democracy (Virta and Branders 2016, 2).

The generic, scholarly notion of "comprehensive security" is also worth discussing before outlining the Finnish version in practice. In academic literature, the concept of comprehensive security is characterised from a holistic point of view as a target, a process, or the ideal state. The interpretative framework can be systemic or dynamic. Buzan (1991, 364-368) creates both systemic and complex perspectives with regard to security to capture the connotations of comprehensive security. According to Buzan, security issues can be described as more systemic problems. Political, military, economic, societal, and environmental factors are seen as interacting factors. The Organisation for Security Cooperation in Europe's definition 
emphasises politico-military security, but also human rights and security democratic standards, economic and ecological aspects (Ministry for Foreign Affairs 2013).

Comprehensive security is alternatively interpreted as both a conceptual approach and a governance model. It is thought to be the key concept of security policy and a goal that is achieved by coordinating non-state and state instruments and elements (Fitz-Gerald and Macnamara 2012, 4). Narratives associated with the concept usually include arguments that military capabilities are a key security instrument, but in themselves an inadequate tool, as a changing security environment requires a wider range of means to fight against modern security threats (see Fitz-Gerald and Macnamara 2012; Kauner and Zwolski 2013; Rieker 2006).

Branders (2016) studies the phenomenon of comprehensive security and recognises seven dimensions through which the notion of comprehensive security can be framed in political discourse (e.g. in security policies and policy papers): (1) the use of "broad security" as a policy and strategic doctrine, involving unifying and holistic security thinking; (2) "comprehensive security" as requiring ongoing and continuous processes, and taking into account global flows and systems; (3) the development of a stable and peaceful society, including the welfare dimension and "human security"; (4) comprehensive defence (linked to "Total Defence", as discussed below);

(5) preparedness and continuity management; (6) the operational dimension of public authority cooperation; and (7) the ecological dimension (Branders 2016). Comprehensive security can also be seen as a matter of strategic state. The idea of strategic state includes common preparatory work, focusing on citizens' needs and democracy (Murphy 2014, 243-244).

Despite the widespread use of broadening security concepts, especially in the Nordic region, the Finnish CSM is unique in several ways. First, as we will see below, the CSM emerged from a distinct historical context. As for other Nordic states, that context was rooted in a Total Defence-like security approach. Finland's defence, however, differs over the years in its stance and relation to powerful neighbouring states like Russia. Second, general comprehensive security concepts tend to cover broad security threats and even safety issues (which in Finland are combined in the word turvallisuus). In Finland, however, broad security notions have been implemented and defined through the specific adoption of the model. The CSM emphasises, in short, how to operationalise comprehensive security - and it does so by suggesting governance approaches such as the collaboration of the security actors involved in planning and conducting preparedness (Security Committee 2017, 93). We now outline precisely what the CSM in Finland looks like.

\section{The Finnish CSM in a nutshell: securing the vital functions of the society}

The Finnish approach to comprehensive security takes the form of a model outlined in a series of government documents, both strategic and policy. In 
essence, the CSM includes a broad array of threats and necessary responses, and includes the full range of action from pre-emption to crisis management and recovery, but is primarily directed towards implementation of those ideas by (a) focusing on coordination across and between governance levels, (b) taking a phenomenon-led approach, (c) being solidly built on the rule of law, and (d) emphasising preparedness.

The most recent and illustrative description of the Finnish CSM can be found in the Security Strategy for Society, which is a Government Resolution from November 2017. The foundation of that Security Strategy is collaboration between security actors. That means collaboration between authorities, the business community, and organisations - even citizens while respecting the clear responsibilities of different authorities. Today, the private sector plays an important role in the CSM. The authorities secure the vital functions of the society with the assistance of private companies. In this regard, the capacity of non-governmental organisations (NGOs) is important, especially in the latter phases of a crisis or, for example, in the event of a migration crisis. It is good to remember that there are some 130,000 registered associations in Finland which serve a variety of purposes.

The strategy reflects the core principles of the comprehensive security approach in Finland by outlining the importance of safeguarding the vital functions of the society: leadership, international and European Union (EU) activities, defence capability, internal security, economic infrastructure and security of supply, functional capacity of the population and services, psychological resilience (Security Committee 2017). The idea of having seven "vital" functions instead of a long list of critical functions is to provide guidance for thinking collaboratively. The interconnection and interdependence between various vital functions require information sharing and collaboration. Understanding the connections - and even beyond - raises joint awareness and builds trust.

The CSM is characterised by four major components. Starting with coordination and cooperation, the Finnish CSM has been developed as a process aiming towards better coordination amongst national security authorities, local authorities, organisations, and citizens. The model also takes into account the requirement of foresight on the security governance level. The term "comprehensive" has often been used in connection with crisis management as a comprehensive approach or framework (Mero 2009). Indeed, it regards a crisis as a process.

Coordination at the national level is centred on the Security Committee, which is responsible for facilitating the networked demands of comprehensive security. These collaborative forums, supported by various secretariats, meet regularly in order to share information, discuss security issues brought up by the members, and plan preparedness exercises. In practice, the Finnish CSM provides a model for municipalities and regions as well.

By having monthly or quarterly meetings with collaboration forums consisting of authorities, private companies, and NGOs, it is possible to 
concentrate on how to reach another level of security actors: the citizens. Citizens are considered security actors in the Security Strategy for Society (2017), which reflects the desire to involve and motivate individuals to ensure their own resilience. New methods have been developed in order to motivate people. One good example is the "72 hours concept" (https://72tuntia. fi/en/) of the Finnish National Rescue Association. The 72 hours concept details the level of domestic preparedness recommended by the authorities and NGOs, so that the average citizen might survive for 72 hours without state assistance. The dialogue between authorities and citizens has been improved with the concept of "Security Cafés". The Security Café is a deliberation and data collection method developed for the use of security authorities and researchers to access the general public opinion on safety and security issues. It is based on the ideals of deliberative democracy, and the method derives from Citizens' Juries and World Cafés (Puustinen et al. 2020). The study on Security Cafés showed that people are willing and able to participate in local security planning and information sharing (Jalava et al. 2017).

Second, the Finnish CSM has been developed on a phenomenon-based approach, meaning that the development of security collaboration has emerged because of practical needs rather than administrative decisions. For example, the collaboration concept of the Border Guard, Customs, and Police has been developed through practical needs. The security phenomena do not follow the administrative sectors and therefore collaboration is required. This phenomenon-based orientation has penetrated even into the latest government programmes (Sitra 2018). Phenomenon-based security collaboration provides actors with incentives to work in an appropriate, feasible, timely, and proportionate manner. It also has an internal dynamic that allows for a future-oriented, more anticipatory way of working, compared to sectoral goal setting. According to Lähteenmäki-Smith and Virtanen $(2019,3)$ a phenomenon can be understood as a simple object of observation, something that is perceived, the reasons or explanations of which being ambiguous and the fundamental causalities or determining dimensions not being directly distinguished. Such phenomena need thus to be understood more comprehensively, from various points of view, systematically and beyond administrative or disciplinary boundaries.

Third, the rule of law is an important component to the CSM. The competent authority carries the main responsibility for planning and action in different emergencies and disruptions. In most cases, regular legislation is sufficient. However, when necessary, and if the conditions turn out to be unconventional, the Emergency Powers Act may give more capabilities and powers to different authorities. For example, Ministry of Transport and Communications may prioritise the use of traffic or communication networks for the authorities. The act also includes preparedness obligations for unconventional circumstances (Finlex 1552/2011).

Fourth, in the field of preparedness, the principle of being proactive in order to reduce costs and improve security has created foresight processes. 
They are integrated into the Finnish model of Comprehensive Security today (Security Committee 2017). The foresight process within the Security Committee every year is a good example of that. It utilises several networks of expertise, and the end product is evaluated by an official collaborative forum for the use of state leaders (called a Cabinet Report). In addition, security of supply utilises the foresight process within the same processes (Huoltovarmuuskeskus 2018).

\section{The development of the concept}

The following discussion will present the development of the CSM in four steps. The first lays out the defence origins of the concepts, which is followed by a description of its leading principle, which we term as pragmatism. The third step reviews the threat-based planning that has occurred in the face of a changing security environment for Finland. Finally, a fourth step sets out the arguments used in favour of a "comprehensive approach".

\section{The defence origins of comprehensive security}

The Finnish model of comprehensive security can be traced to the first decade of the country's independence. Soon after the declaration of independence in 1917, Finns had to face a civil war, which was the outcome of the Bolshevist revolution encouraging the Finnish Red Guards to start a revolution. The state's troops, the White Civil Guards, later supported by volunteers trained in Germany, the Finnish Jägers, and even German troops suppressed the revolution in May 1918. The aftermath was bloody, with the White side punishing the Reds (Tepora and Roselius 2014). The scars of the civil war were deep and still recognisable in the rhetorics of people and media even today, which was notable in social media during the centennial commemorations in the spring of 2018.

The building of regular security structures began immediately after the end of the civil war. In the early decades, the building of national security concentrated on the border guard and defence forces. In late 1918, the White Guards played an important role in the establishment of a police force (Hietaniemi 1992). The border in the east was very restless and required militarily organised troops, yet organised in a European manner under the Ministry of the Interior. The security situation in Karelia remained unstable even after the Treaty of Tartu in 1920. Finnish voluntary expeditionary troops moved over the eastern border in order "to liberate Karelian tribes" in the Soviet Union between 1918 and 1922. These so-called tribal wars were more or less improvised manoeuvres, and reflected the uncertain political atmosphere of the first years of Finland's independence (Niinistö 2005).

In 1924, the first state level collaborative body, the Defence Council was established. The Ministry of Defence, Chief of the Army, Chief of the Civil Guard, and officers from the Headquarters constituted the Council. 
It focused on the establishment of garrisons and material procurements. It was very soon supported by the Economic Defence Council, which was chaired by a senator and consisted of civil servants, CEOs, and bank managers (Tervasmäki 1983).

The 1920s and 1930s were the early decades of the building of the nation's security structures. Finland's own defence solutions and development of operational art and tactics and material were rather unique. The military concepts used in the First World War and the leading European countries were not applicable to the Finnish context, so many domestic innovations were put in practice; the Suomi-submachine gun, ski troops using sledges and tents with stoves proved to be very effective in action (Hollanti 2019).

The Finnish collaboration capabilities were put to a test during the Second World War. The so-called Molotov-Ribbentrop Pact ${ }^{1}$ between the Soviet Union and Germany led to the Winter War in 1939-1940. The Soviet Union started its campaign to occupy Finland in November 1939 (Kivimäki 2012; Varrak 2016). Despite the poor material capability of the Finnish Defence Forces, Soviet attacks were stopped by using tactical and technical innovativeness supported with a strong will to defend the country. The concentrated masses of Soviet troops broke through at Summa on the Karelia Isthmus in February 1940, which urged Finnish politicians to seek peace, even with harsh conditions. The Finnish Army was exhausted after three months of fierce fighting, practically without reserves. Western European countries' eagerness to support Finland turned out to be rhetorical and only quite modest support arrived from other countries. Swedish volunteers made an exception, as they contributed to the defence of Lapland, which helped Finnish troops to concentrate on the most critical areas in Karelia and on the coast of the Gulf of Finland (Ahto 1990; Kivimäki 2012; Vehviläinen 2002).

Against all odds, Finland was able to remain independent. The losses were big, but the morale was relatively strong. This had a socio-historical impact on collaborative thinking and support in the country. For example, one interesting feature is that merely two decades after the Civil War, there no longer was a sense of a strong divide between "Red" or "White" Finns, only Finnish citizens fighting for their fatherland. That had been a miscalculation from the part of the Soviets who thought that the Finnish working class would support the Red Army and the Soviet Komintern. On the contrary, the surprising outcome of the Winter War built up the narrative of the Finnish success story and unified the people (Ahto 1990; Kivimäki 2012).

The next phase of the Second World War was fought in an alliance with Germany. This was a politically sensitive issue, and Finnish politicians wanted to emphasise that Germany was not an "ally"; Finland was only fighting alongside Germany in order to reclaim what was lost in the Winter War peace agreement in Moscow in 1940. Of course, Finland was still widely considered to be in alliance with Germany, despite the attempt to avoid such a view on the political level (Vehviläinen 2002). 
Finland recovered the lost areas of Karelia and access near Leningrad and the Murmansk railway as a part of Germanys' offensive against the Soviet Union in 1941. This so-called Continuation War from 1941 to 1944 ended poorly after the first years' success. The outcome was even worse than that of the Winter War. Karelia was lost again. Petsamo was lost with access to the Barents Sea. Still, Finland had to pay the equivalent of 300 million dollars in goods in war reparations to the Soviet Union 1944-1952 (Rautkallio 2014). Germany had been fighting alongside Finns in the Finnish Lapland, but now Germans had to be forced out of the country. The Lapland War between former allies was the last stage of the Second World War for Finns, ending in the spring of 1945 as the last Germans left Finnish soil (Ahto 1980; Kivimäki 2012). Once again, Finland managed to remain independent.

\section{Pragmatism as principle}

The devastating years of the Second World War resulted in hundreds of thousands of refugees from Karelia, 90,000 people having lost their lives, and the entire country being exhausted. As Finland had been forced to mobilise the whole nation in order to support its armed forces and survive, the concept of Total Defence was developed during and after the war. Since then, Finns have had a strong national will to defend their country, which has built both confidence in authorities and a willingness to work together. These features remain important cornerstones of building comprehensive security today (Ries 1988). Indeed, the lesson of the Second World War clearly suggested to the security establishment that a small country could not survive on its own for long. On the other hand, it was problematic to be allied to a partner that you could not really influence. The difficult alliance with Germany during the Continuation War 1941-1944 led to a war in Lapland against the former ally. This drastic experience has led to the dominance of pragmaticism as a principle in Finland, not only with regard to military alliances but also concerning broader efforts to security society.

During the Cold War, for example, the Soviet Union pressured Finland to keep a distance from other Western countries. This cognitive notion of Finland being regarded as "separate" from the rest of the world became institutionalised in official and unofficial thinking (Aaltola et al. 2014). This led to the famous Finnish mindset of go-it-alone isolationism captured by the Finnish word "impivaara". ${ }^{2}$ Indeed, from the late 1940s to the early 1990s, Finland's difficult balancing act between accepting Soviet pressure and trying to be part of the West gave birth to the term "Finlandization" (Aaltola et al. 2014, 160; Salminen 1999).

Despite these difficulties, the necessary focus on self-reliance led to pragmatic solutions and new innovations, especially in the field of security collaboration. They could be described as the nation's "survival methods", including security of supply during the early stages of comprehensive security. As reviewed earlier, Total Defence, including economical preparedness 
and territorial defence, made up a solution that served as a common framework for preparing for war (Hollanti 2019). It also set the criteria for preparedness for the civil society.

Key to these innovations was the Finnish Defence Council, which restarted its activities in 1958 after being in silence mode during and after the Second World War. From this time, the Council helped devise the fundamental components of Total Defence that were organised and created from 1958 to 1966, detailed in the previous sections. Preparedness plans and organisations were formulated in the most important sectors of the society such as the economy, medical supply, telecommunication, and civil defence. Even scientific and psychological forms of resilience were organised. Highlighting the interplay of education and policy, as in Sweden (Larsson, this volume), so-called "national defence courses" were created then to provide comprehensive Total Defence education for key leaders in the beginning of the 1960s (Tervasmäki 1983).

Pragmatism, it can be said, led to a willingness to coordinate in Finnish government. For example, one significant success factor in security collaboration has been interagency collaborative forums at the state level. This started in the 1970s and 1980s, when the Finnish Defence Council engaged in high-level cooperative initiatives to improve Total Defence solutions. The President of the Republic or Prime Minister chaired the Council, while "Preparedness Chiefs" met in collaboration forums since 1978. Every ministry designated a security expert as its chief of preparedness. Their task was to support ministerial and governmental preparedness planning and incident management (Parmes 2019; Tervasmäki 1983). Chiefs of preparedness were either permanent secretaries of the ministries or other security experts, so the discussions were high-level and often led to concrete results. The secretary and, later, Chief of Preparedness of the Ministry of Communications and Traffic, Rauli Parmes, pointed out many successful collaborative actions concretised via the collaboration forums. One example is the TETRA-communication system for security authorities. The relevant authorities created a common communication system with the support of business community service providers in the 1980-1990s (Parmes 2019). The system is still valid and operative in the current generation of collaborative forums. As we can see, then, the foundation for much of what we see in today's formulation of Finnish comprehensive security was set years earlier through the history, and defensive posture, of Finland towards its external security environment along with a degree of pragmatism in coordinating across governmental structures.

\section{A widening threat environment}

At the same time, perceptions of a changing security environment added additional pressure to change the strategic doctrines of Finnish security policy. For instance, at the turn of the millennium, developments in the 
security environment and changing threat scenarios pushed Finland's domestic policies to recognise cross-border interdependencies (Aaltola et al. 2014; Fjäder 2016). The collapse of the Soviet Union in the beginning of the 1990s and Finland's entry into the EU in 1995 were the most important turning points in this respect. Finland's EU membership made it possible for the country to improve its Western security collaboration. Soon enough, the NATO Partnership for Peace programme opened possibilities for Finland for strengthening military collaboration in various branches (Aaltola et al. 2014; Michel 2011). For Finland, security was a very important reason for joining the EU (Tiilikainen 2015).

In the late 1990s, war was no longer the "worst case scenario" for preparedness planners, since unintentional threats had joined intentional threats on the perceived threat spectrum. As for other Nordic countries, discourses emerged to suggest that Finland needed to have a more comprehensive approach to security. For example, many likeminded Western countries started to develop their critical infrastructure protection (CIP) concepts (Hagelstam 2005), and Finland followed suit. In late 2003, the Finnish government approved the first strategy for securing the vital functions of society. That was the first strategy providing common planning instructions involving threat scenarios for vital functions that needed to be secured in any circumstances, including general guidelines for managing a diverse array of security incidents (MoD 2003). The strategy was updated three times, leading first towards more specific preparedness planning. The strategy in 2006 represented for the first time the strategic tasks (counting 50) for ministries and disruption models (counted at 64) which required collaborative planning, thus reflecting the phenomenabased thinking discussed earlier. The second update in 2010 outlined the key aspects of a "comprehensive approach". Ministerial tasks in the field of security of supply, for instance, were introduced as a new feature (Ahokas 2019; MoD 2006, 2010). The last update focused on creating general preparedness principles for supporting long-term planning and over the parliamentary terms.

During these years, the model of Total Defence gradually evolved into the Finnish concept of comprehensive security (see e.g. Hallberg Report, Valtioneuvoston kanslia 2010). It was based on an all-hazards principle, which placed central responsibility to the competent authority, placing all other relevant security actors in supporting roles. Involving all relevant security actors locally and regionally already at the planning phases in e.g. risk assessment ensured a shared situational understanding via information sharing. Training together was supposed to build trust and result in better preparedness. It can be argued that training for storms and natural hazards, for example, creates capabilities to manage not only man-made disasters but also hostile attacks. In both cases the actors use risk management models, share situation picture, do cross-agency co-ordination (Ministry of Interior 2018). 
The shift from Total Defence to the comprehensive approach took place little by little in the beginning of this millennium. Total Defence could be criticised as a militarisation of the nation. These notions among others were weighed when the so-called Hallberg Committee examined the development needs especially with regard to Total Defence and comprehensive security (Valtioneuvoston kanslia 2010). The Committee Report suggested the current comprehensive approach. It suggested that the term Total Defence should be replaced with comprehensive security and the Defence and Security Committee should be called Security Committee. Other suggestions concerned information sharing and improvement of situational picture and awareness.

The shift from Total Defence to the comprehensive security approach can be regarded as a success. It fits very well with the National Defence Courses as a framework for preparedness education. According to Committee members (see i.e. Blogs from www.turvallisuuskomitea.fi) and several local-regional commentators it has contributed to dialogue and involvement in many practical exercises. It has allowed for a broader approach towards preparedness planning, which contributes to countering hybrid threats. The shift from defence-oriented preparedness to an all-hazards perspective provides more options for private companies and organisations to participate in common preparedness planning and implementation. Still, the comprehensive security concept includes Total Defence, and military exercises are conducted regularly in all parts of Finland (Ahokas 2019).

\section{Political backing of comprehensive security}

Political backing of the Comprehensive Security Model has remained strong. The model leans on principles of coordination instead of command and control. The rule of law and the principle of competent authority are highly respected. According to Branders (2016), the concept of comprehensive security has "positive valence" due to its holistic and promising nature as a target state. Furthermore, according to Patton et al. (2013), political viability means that a phenomenon is acceptable and it meets the requirements set for it. However, more attention should still be paid to the cooperation of security authorities on all levels of society, and in every phase of the planning process (Branders 2016, 146-150).

The comprehensive approach continues to enjoy high political backing. In 2019, the approach of Prime Minister Antti Rinne was repeated by Prime Minister Sanna Marin: "Preparedness will be carried out in line with the comprehensive approach to security and by developing the statutory basis" (Valtioneuvosto 2019b). In the official government programme, areas of development were represented phenomenon by phenomenon. This approach was a significant improvement from the comprehensive security point of view. That reflects the same approach which has been visible in security planning through the development of the security strategies for society. 
Understanding the necessity of comprehensive thinking among politicians and key leaders from every vital branch is supported via National Defence Courses. Most of the members of Parliament, top CEO's of critical infrastructure companies, NGO leaders, media leaders, cultural influencers, artists, and university personnel have attended the 3.5-week National Defence Course. The context comes from the CSM, and the 2017 Security Strategy for Society more specifically. The eagerness to participate in those courses expresses the will to take national security aspects seriously. At the moment, there are 600 Finnish top leaders queuing for the course, but only 200 are signed up per year. The courses have built shared understanding and practitioner networks despite differing political views since 1961.

The positive orientation towards domestic security cooperation is also supported by general conscription, and the fact that a significant number of leaders have a reserve officer rank. Conscription for men and voluntary women creates bonds not only among conscripts and reservists but also makes the military a visible and normal part of society. This contributes to the strong willingness of Finns to defend their country. In 2015, Europeans were asked: "Would you fight for your country"? Over 74 per cent of Finns were willing to defend their country when the average in other Western European countries was around 25 per cent (Minister of Defence, Antti Kaikkonen speech 20.1.2020).

In short, the current Finnish approach to comprehensive security is strongly shaped by the history of Finland and its geographical situation with 1,300 kilometres of border with Russia. This is not just a military matter. The relationships between the two countries are of utmost importance for decision makers. At the same time, Cold War pragmatism and a widened threat environment have made Finland willing to forge collaborative responses to modern security complexity, an issue we further explore in the next section.

\section{Future ambitions: managing complexity through the CSM}

As discussed, the Finnish version of comprehensive security crystallises in the form of an operational model intended to steer multiple actors in a complex security environment. Indeed, a key work used in Finnish security discussion is "complexity" - both of the threat environment and threats themselves. Here we discuss how CSM is intended to help manage that complexity and the challenges that remain.

According to Hanén (2017) complexity must be responded to by creating structures that facilitate a more horizontal situational awareness by practitioners, and by reforming structures in ways that make them less hierarchical and rigid. The CSM creates both an agenda for a more phenomenon-based security governance platform, and responds to the needs for cooperation in anticipating trends, threats, and useful practices. Furthermore, the systems of (security) governance need to be more adaptive and, for example, experimentation and exploration are required in complex adaptive systems: they 
cannot be served by linear public policy intervention models, targeting only one area of policy development, one agent or actor, or individual policy sector. Therefore, the useful framework for addressing such societal security challenges is the CMS's phenomenon-based system described in section "The Finnish CSM in a nutshell: securing the vital functions of the society" (see also Lähteenmäki-Smith and Virtanen 2019; Sitra 2018).

To be sure, the Finnish CSM is still a work in progress. New challenges emerge from new complex threats and societal risks identified on a regular basis, and calls have been made to ensure the CSM is even more processoriented and allows for smoother movement between different administrative sectors (silos) and levels. The core principle of collaborative planning has enabled the possibility of thinking about phenomena out of the box, and other "black swans". For example, when the Ministry of Justice started its campaign to raise awareness on possible election interference, the matter was brought to the Security Committee, which gave its support and prompted an analysis, using both permanent and ad-hoc networks. The outcome was information packages for raising awareness of different audiences, and several concrete capabilities and suggestions to encounter hostile information influencing. According to the committee, these actions represented better preparedness to prevent election interference, even if we cannot say to what extent (Valtioneuvosto 2019a).

As has been argued (Innes and Booher1999; Shine 2015; Thomas 2012), complexity is problematic only if we try to solve the drivers and consequences of complexity with old mindsets: such systems require adaptive and reflexive policy-making to fit the needs of such a system (Lähteenmäki-Smith and Virtanen 2019). Knowledge and learning are also features of a complex adaptive system (Eidelson 1997). Learning creates shared meanings and knowledge. To that end, the Finnish CSM arguably offers platforms that are ideal for dealing with complexity. Networked information sharing seems to be rather unique in the Finnish concept, because the private sector and NGOs are included as security actors at every level of action, including at the planning stage. At the local and regional levels, many actors reap the benefits of comprehensiveness, because the Finnish approach encourages round table collaboration and information sharing, especially with the business community and NGOs, which otherwise tend to have problems achieving synergies in exercises and operative action. Furthermore, a lack of resources in many areas in Finland has created innovative solutions on how to share the burden. For example, a collaboration model between the Border Guard, Customs, and Police developed in rural Lapland precisely because of limited resources, and is now used as an example of effective planning and coordination thanks to new security mindsets.

\section{Conclusions and implications}

The Finnish security concept might seem quite unique in comparison with those of the other Nordic countries. It developed from a specific historical 
context - repeated conflict with, and influence from Russia - and the resulting defensive posture and societal solidarity taken. Moreover, the Finnish approach to comprehensive security is less conceptual, one might argue, and more operational. It is used to underpin a CSM and to steer cross-sector, multi-level governance towards managing an array of threats. It includes pragmatic benchmarking of security goals, such as in security of supply, is upheld by centralised governance structures such as the Finnish Security Committee, and highlights preparedness planning to a great extent. It is, as argued earlier, as much about practical action as it is about conceptual understanding.

However, a number of Nordic similarities emerge from this analysis, too. First, the Finnish approach is reminiscent of a "societal security" perspective and, as pointed out in section "The comprehensive security concept in comparative perspective", related concepts such as resilience. It encompasses a wide range of threats, implies a broad number of responses, and places an emphasis on effective coordination. Second, the Finnish approach should be seen as emerging from, not distinct to, the previous Cold War notion of "total defence" that was present in several Nordic countries, not least Sweden and Norway (see also Larsson, and Morsut, respectively, this volume). Comprehensive security built on the mindsets (including deep levels of societal trust) and structures what existed before, while filling a conceptual vacuum that opened during the early 1990s. Third, Finland's broad security approach is central but not dominant in national security practices, as highlighted by differences witnessed in national strategic choices (e.g. Telford 2016, see also Hyvönen and Juntunen, this volume).

To be sure, these similarities assist and shape Finland's cross-border cooperation, for instance in its defence collaboration with Sweden today (Fjäder 2016; Valtonen 2010). The broad approach to security likely facilitates relations with the EU, too, which as discussed earlier, shares some conceptual affiliations with the comprehensive approach (particularly, societal security) and through which Finland achieves security collaborations. The same goes for NATO. Finland's comprehensive approach no doubt eases relations with diverse other partners in various activities associated with the Partnership for Peace programme (Aaltola et al. 2014). The Finnish CSM raises interest in many countries, which suggests that all states are considering how they organise or conceptualise security, whether they are members of the EU and/or NATO or not.

Indeed, the Finnish CSM model assists with platform-based networking collaboration across Finland, and works well in many cases. However, problems remain - many of them related to poor resourcing. New political leaders are elected every four years and financial allocation is mostly planned in four-year governmental phases. Long-term development and planning can thus be challenging because of fast changes in the policy and security environment or due to fluctuations in economy. This has implications especially for comprehensive security planning, where steady and shared 
perspectives are helpful. Even with strong incentives to cooperation via the CSM, there are equally strong incentives to engage in bureau-politics. There are rivalries between administrative sectors and processes are carried out at different pace among agencies or without proper coordination. Necessary sharing of information within the forum must take place, without leaking information and violating trust in the common good. (Valtonen 2018) Indeed, the Finnish approach to comprehensive security is strongly built on trust, which has to be validated. In these very broad collaboration forums, collaboration skills and faithful implementation are required. Despite the success of the CSM, constant reminders and training in the importance of a comprehensive, anticipatory, and cross-disciplinary preparation approach must take place (Valtonen 2010).

\section{Notes}

1 In the Molotov-Ribbentrop Pact Finland was left to the Soviet Union's sphere of influence.

2 The term "Impivaara" in Finnish describes the traditional stubborn way to try to cope alone. It originates from Aleksis Kivi's 1870 novel Seitsemän Veljestä ("Seven Brothers").

\section{References}

Aaltola, M., Kuznetsov, B., Spruds, A. and Vizgunova, E. (eds.) (2018). Societal security in the Baltic Sea region. Riga: Latvian Institute of International Affairs.

Aaltola, Mika, Käpylä, Juha, Mikkola, Harri and Behr, Timo (2014) Towards the Geopolitics of Flows, Implications for Finland, FIIA Report 40. Helsinki: The Finnish Institute of International Affairs.

Ahokas, Jussi (2019) Suomalaisen kokonaisturvallisuuden turvallistaminen kylmän sodan jälkeen. Finnish: Pro Gradu, Maanpuolustuskorkeakoulu, Finnish National Defence University.

Ahto, Sampo (1980) Aseveljet vastakkain - Lapin sota 1944-1945. Helsinki: Kirjayhtymä.

Ahto, Sampo (1990) Talvisodan henki. Juva: WSOY.

Branders, M. (2016) Kokonainen turvallisuus? Kokonaisturvallisuuden poliittinen kelpoisuus ja hallinnollinen toteutettavuus. [Comprehensive Security? The Political Viability and Administrative Operability analysis]. Acta Universitatis Tamperensis 2124. Tampere: Tampere University Press.

Buzan, Barry (1991) People, States and Fear: An Agenda for International Security Studies in the Post-Cold War Era. London: Harvester Wheatsheaf.

Eidelson, Roy J. (1997) Comple.x Adaptive Systems in the Behavioral and Social Sciences. Review of General Psychology 1 (1), 42-71.

Fitz-Gerald, Ann and Macnamara, Don (2012) Comprehensive Security Requires Comprehensive Structures - How Comprehensive Can We Get? Strategic Studies Working Group Papers. Ottawa: Canadian Defense \& Foreign Affairs Institute.

Fjäder, Christian (2016) National Security in a Hyperconnected World: Global Interdependence and National Security, In Masys, A.J. (toim.) Exploring the Security Landscape: Non-Traditional Security Challenges, London: Springer, s. 31-58. 
Hagelstam, Axel (2005) CIP - kriittisen infrastruktuurin turvaaminen. Helsinki: Huoltovarmuuskeskus.

Hanén, T. (2017) Yllätysten edessä. Doctoral Dissertation. National Defence University, Finland.

Hietaniemi, Tuija (1992) Lain vartiossa - Poliisi Suomen politiikassa 1917-1948, Suomen Historiallinen Seura, Vammalan Kirjapaino Oy.

Hollanti (2019) Alivoimaisen taktiikka, Dissertation, FNDU.

Jalava, J., Raisio, H., Norri-Sederholm, T., Lahtinen, H. and Puustinen, A. (2017) Kolmas sektori vi-ranomaisten turvallisuustoiminnan tukena [The Role of the Third Sector in Supporting Public Authorities' Security Functions]. Publications of the Government's Analysis, Assessment and Research Activities 76. Helsinki: Finnish Government.

Kauner C. and Zwolski K. (2013) The EU as a Global Security Actor. A Comprehensive Analysis Beyond CFSP and JHA. USA: Palgrave Macmillan.

Kivimäki, Ville (2012) Finland in World War II - History, Memory, Interpretations. Series: History of Warfare, Volume: 69, Brill.

Lähteenmäki-Smith, K. and Virtanen, P. (2019) Complex Societal Phenomena, Mission-Oriented Public Policy and the New Evaluation Culture. In Lehtimäki, Hanna, Uusikylä, Petri and Smedlund, Anssi (eds.) Society as an Interaction Space: A Systemic Approach. London: Springer.

Martikainen, Toivo, Katri, Pynnöniemi and Sinikukka, Saari (2016) Neighbouring an Unpredictable Russia. The Finnish Institute of International Affairs, FIIA.

Mero, Tuomo (2009) Kansainvälisen kokonaisvaltaisen kriisinhallintastrategian (Comprehensive Approach) mahdollisuudet Suomen kokonaismaanpuolustuksen kansainvälisen ulottuvuuden kehittämiseen. Voimakasta normipainetta vai hienosäätöä? Master's thesis required for Diploma, Maanpuolustuskorkeakoulu, Finnish National Defence University.

Michel, Lee G. (2011) Finland, Sweden, and NATO: From 'Virtual' to Formal A1lies? Strategic Forum. Number 265, February.

Ministry of Defence (2003) The Government Resolution on Securing the Functions Vital to Society.

Ministry of Defence (2006) The Government Resolution on Securing the Functions Vital to Society.

Ministry of Defence (2010) The Security Strategy for Society.

Ministry of Defence UK (2018) Global Strategic Trends. The Future Starts Here. https://assets.publishing.service.gov.uk/government/uploads/system/uploads/ attachment_data/file/771309/Global_Strategic_Trends_-_The_Future_Starts_ Today.pdf

Ministry for foreign affairs for Finland (2013) Mission and tasks of the OSCE. https://um.fi/ulko-ja-turvallisuuspolitiikka-kansainvalisissa-jarjestoissa\#Etyj (28.8.2013)

Ministry of Interior (2018) Kansallinen riskiarvio 2018 National Risk Assessment 2018, Publications of the Ministry of the Interior 2019:5. Helsinki: Finnish Government. http://julkaisut.valtioneuvosto.fi/handle/10024/161332

Murphy, P. (2014) The Development of the Strategic State and the Performance Management of Local Authorities in England. In Joyce, P. and Drumaux, A. (eds.) Strategic Management in Public Organizations. European Practices and Perspectives. New York: Routledge, 243-254. 
National Emergency Supply Agency (Huoltovarmuuskeskus) (2018) Security of Supply Scenarios 2030. https://cdn.huoltovarmuuskeskus.fi/app/uploads/ 2018/09/06091431/Eng-Scenarios-2030.pdf

Niinistö, Jussi (2005) Heimosotien historia 1918-1922, SKS, Hämeenlinna 2005.

Nordforsk (2013) Societal Security in Nordic Countries. Policy Paper 1 - 2013.

Parmes, Rauli (2019) Siviilivarautumisen historia: kriisit ja hallinto. Mediapinta Oy.

Patton C., Sawicki D.S. and Clark J.J. (2013) Basic Methods $f$ Policy Analysis and Planning. 3rd edition. New Jersey: Pearson Education Inc.

Puustinen A., Raisio H. and Valtonen V. (2020) Security Cafés: A deliberative democratic method to engage citizens in meaningful two-way conversations with security authorities and to gather data. Lehtimäki H., Uusikylä P., Smedlund A. (eds.) 2020. Society as an interaction space: a systemic approach. Springer.

Rautkallio, Hannu (2014) Suomen sotakorvaukset 1944-1952: mahdottomasta tuli mahdollinen, Paasilinna, Helsinki.

Rieker, Pernille (2006) From Common Defence to Comprehensive Security: Towards the Europeanization of French Foreign and Security Policy? Norwegian Institute of International Affairs (NUPI), Security Dialogue 37, 509-528.

Ries, Tomas (1988) Cold Will-The Defense of Finland. New York: Brassey's Defence Publishers.

Salminen, Esko (1999) The Silenced Media: The Propaganda War between Russia and the West in Northern Europe. Translated by Jyri Kokkonen. New York: St. Martin's.

Security Committee (2017) The Security Strategy for Society. Government Resolution. Helsinki: Security Committee.

Security Committee (ed.) (2018) National Defence Courses. Turvallinen Suomi, Lönnberg Print \& Promo, Helsinki 2017.

Sitra (2018) Phenomenon-Based Public Administration. Discussion Paper on Reforming the Government's Operating Practices. Sitra Working Papers.

Telford, Jan (2016) Power of the Future: Security of Supply in Danish and Finnish National Energy and Climate Strategies. Master's thesis, University of Tampere 2016.

Tepora, Tuomas and Roselius, Aapo (eds.) (2014) Finnish Civil War 1918. History, Memory, Legacy. Leiden; Boston: Brill.

Tervasmäki, Vilho (1983) Puolustusneuvosto vuosina 1958-1983, K.J. Gummerus, Jyväskylä.

Tiilikainen, Teija (2015) Now Security Policy is a Factor in Finland's General Election. www.friendsofeurope.org/views/now-security-policy-factor-finlandsgeneral-election

Valtioneuvosto (2019a) Vaalivaikuttamisen koulutushankkeen loppuraportti, 2019:22 (Finnish Government: Final Report on Training to Raise Awareness of Election Interference), Helsinki.

Valtioneuvosto (2019b) Programme of Prime Minister Sanna Marin's Government 10 December 2019. Inclusive and competent Finland - a socially, economically and ecologically sustainable society. Publications of the Finnish Government 2019:33.

Valtioneuvoston kanslia (2010) Varautuminen ja kokonaisturvallisuus. Komiteamietintö.

Valtonen, V. (2010) Turvallisuustoimijoiden yhteistyö - operatiivis-taktisesta näkökulmasta. Collaboration of Security Actors - An Operational-Tactical View. 


\section{Vesa Valtonen and Minna Branders}

Dissertation in Finnish, Nation Defense University, Helsinki. [Conference Paper at the 2010 ISMS Conference, Stockholm, Sweden.]

Valtonen, V. (2018) Nähtiinkö kokonaisturvallisuutta, nähtiinkö hybridiä? Did We See Comprehensive Security, Did We See the Hybrid? In Finnish. Tuleva sota, Nykyhetki ennakoinnin valossa. Helsinki: Maanpuolustuskorkeakoulu, Edita, ss. 147-159.

Varrak, Toomas (2016) The Secret Dossier of Finnish Marshal C.G.E. Mannerheim: On the Diplomatic Prelude of World War II, Perceptions. Journal of International Affairs XXI ( Part 2), 81-102.

Vehviläinen Olli (2002) Finland in the Second World War. Between Germany and Russia. London: Palgrave Macmillan UK.

Virta, S. and Branders, M. (2016) Legitimate Security? Understanding the Contingencies of Security and Deliberation. The British Journal of Criminology 56 (6), 1146-1164, Published: 18 February 2016. doi:10.1093/bjc/azw024. 